\title{
Growth and grazing responses to temperature and prey concentration of Condylostoma spatiosum, a large benthic ciliate, feeding on Oxyrrhis marina
}

\author{
Chengchun $\mathrm{Li}^{1,2}$, Kuidong $\mathrm{Xu}^{1, *}$, Yanli Lei ${ }^{1}$ \\ ${ }^{1}$ Institute of Oceanology, Chinese Academy of Sciences, Qingdao 266071, PR China \\ ${ }^{2}$ Graduate University of Chinese Academy of Sciences, Beijing 100049, PR China
}

\begin{abstract}
Condylostoma is as a group of very large-sized ciliates frequently dominant in various marine benthic microbial communities. However, little is known about the effects of temperature and food concentration on its growth and grazing. Here, using the heterotrophic dinoflagellate Oxyrrhis marina as prey, we determined the specific growth rate, cell volume, specific production, and ingestion rate of C. spatiosum at different temperatures and prey concentrations. These growth and grazing parameters typically followed a hyperbolic response to prey concentration. By applying iterative curve-fitting to the data at each temperature, we found that, with increasing temperature, the maximum specific growth rate, maximum specific production, and maximum ingestion rate of C. spatiosum generally increased, while the maximum cell volume decreased. The gross growth efficiency of C. spatiosum generally decreased at saturated prey concentration from about 45 to $25 \%$ as the temperature increased from 12 to $24^{\circ} \mathrm{C}$. By fitting these data iteratively to multi-variable nonlinear models, we obtained predictive equations for the growth rate, cell volume, and ingestion rate with respect to temperature and prey concentration.
\end{abstract}

KEY WORDS: Benthic ciliate $\cdot$ Growth rate $\cdot$ Ingestion rate $\cdot$ Gross growth efficiency $\cdot$ Prey concentration · Temperature

\section{INTRODUCTION}

Temperature and food availability are key factors affecting the growth, consumption, and food utilization efficiencies of ciliates. Temperature affects various biological functions directly by altering the rate of chemical reactions, and indirectly by altering viscosity and diffusion. Food availability affects feeding by determining the rate at which a grazer encounters food items (Begon et al. 1986). The effect of either temperature alone or food concentration alone on the growth and production of protozoa was usually studied until Weisse et al. (2002) studied the 2 factors simultaneously for a small freshwater ciliate. Kimmance et al. (2006) investigated both factors in detail for the dinoflagellate Oxyrrhis marina and demonstrated that the interactive effect of temperature and prey concentration could alter the outcome of food-web models.
Such studies to date have focused on pelagic protists; no data are available for benthic forms.

Marine benthic habitats are highly heterogeneous and harbor diverse protists, whose abundance and productivity typically exceed those in the water column by one to several orders of magnitude (Fenchel 1969, Epstein 1997, Hamels et al. 2004). It would be particularly interesting to know whether the ecology of these organisms is different from that of pelagic ones. Condylostoma spp. are benthic ciliates that are frequently dominant in terms of biomass in various benthic habitats (Simpson et al. 1998, Madoni 2006). The importance of these ciliates in sediments is related to their high biomass and voracious grazing on various food items, including ciliates, flagellates, and even small metazoans (Fenchel 1968, Lei et al. 2010). C. spatiosum is a large benthic ciliate that feeds preferentially on Oxyrrhis marina, a widely distributed and abundant 
dinoflagellate that has the potential to control red-tide organisms (Jeong et al. 2003, Lowe et al. 2005). In order to gain a better understanding of the effects of temperature and prey concentration on benthic ciliate population dynamics, we investigated the growth and grazing responses of $C$. spatiosum feeding on $O$. marina at a range of temperatures and food concentrations. Based on the data obtained, we developed predictive models that will allow us to estimate the growth and grazing rate of $C$. spatiosum within given ranges of temperature and food concentration.

\section{MATERIALS AND METHODS}

Study organisms. The size of the ciliate Condylostoma spatiosum was on average $700 \times 80 \mu \mathrm{m}(\mathrm{n}=20)$ and the dinoflagellate Oxyrrhis marina was on average $29 \times 16 \mu \mathrm{m}(\mathrm{n}=20)$ in vivo. Both species were isolated from the intertidal sediment of the Licun River estuary at Qingdao, China, in July 2007 and were maintained in Petri dishes containing bacterized rice-grain medium at room temperature.

Experimental design. Experiments were run in Petri dishes (diameter $90 \mathrm{~mm}$ ) in dim light (1.2 to $2.0 \mu \mathrm{mol}$ $\mathrm{m}^{-2} \mathrm{~s}^{-1}$ ) under a $12 \mathrm{~h}$ light:12 $\mathrm{h}$ dark cycle. The experimental volume in each plate was $20 \mathrm{ml}$. Ciliates were taken from the exponential growth phase and were adapted to the experimental temperature and prey concentration for at least $24 \mathrm{~h}$ before the beginning of the experiments.

Growth and ingestion experiments were run separately at the temperatures of $12,15,18,21$, and $24^{\circ} \mathrm{C}$. Each treatment was conducted with 20 prey concentrations ranging from about $8 \times 10^{2}$ to $1.3 \times 10^{4} \mathrm{cells} \mathrm{ml}^{-1}$ (corresponding to 0.21 to $5.69 \mu \mathrm{g} \mathrm{C} \mathrm{ml}^{-1}$ ). The growth experiments lasted $5 \mathrm{~d}$. Ciliate concentration was determined each day by direct count under a stereomicroscope (magnification 15 $\times$, with at least 100 fields counted per plate). The cell size of Condylostoma spatiosum was measured in vivo from microscopic images and the cell volume was calculated assuming a prolate spheroid shape (with a body width to thickness ratio of about 1.5:1). The size of Oxyrrhis marina was also measured in vivo microscopically, and its concentration was determined from a Lugol-fixed sample ( $2 \%$ final concentration) using a Sedgewick-Rafter chamber. Prey concentration was adjusted when it deviated more than $20 \%$ from the initial concentration. The ingestion experiments lasted $2 \mathrm{~d}$. Cell size and concentration of both prey and predator were determined at the beginning and at the end of each experiment. Petri dishes with the same concentrations of $O$. marina but without predators served as controls. To render the study comparable to previous investigations, we con- verted the cell volume $\left(v, \mu \mathrm{m}^{3}\right)$ of prey and predator to carbon units using $C(\mathrm{pg})=0.099 \mathrm{\mu m}^{-3}$ and $\log C(\mathrm{pg})=$ $-0.639+0.984 \times \log v$, respectively (Menden-Deuer \& Lessard 2000).

Calculation of experimental results. The log cell number of ciliates was plotted against time, and linear regression was computed for the exponential phase of growth in each case. The specific growth rate $(\mu)$ of Condylostoma spatiosum was calculated from the slope of the linear regression. The ingestion rate $(I)$ was calculated according to Frost (1972): $I=C_{\mathrm{m}} \times g / R_{\mathrm{m}}$. The grazing rate was calculated as $g=\left[\ln \left(C_{\mathrm{ct}} / C_{\mathrm{c} 0}\right)-\ln \right.$ $\left.\left(C_{\mathrm{t}} / C_{0}\right)\right] / \Delta t_{\text {, where }} C_{\mathrm{c} 0}$ and $C_{\mathrm{ct}}$ are respectively the initial and final concentrations of Oxyrrhis marina in the controls, and $C_{0}$ and $C_{\mathrm{t}}$ are respectively the initial and final concentrations of $O$. marina in the Petri dishes with predators. $R_{\mathrm{m}}$ is the geometric mean of predator concentration during incubation, and was calculated as $R_{\mathrm{m}}=\left(R_{\mathrm{t}}-R_{0}\right) / \ln \left(R_{\mathrm{t}}-R_{0}\right)$, where $R_{0}$ and $R_{\mathrm{t}}$ are the initial and final concentrations of C. spatiosum, respectively. $C_{\mathrm{m}}$ is the mean concentration of prey during incubation, and was calculated as $C_{\mathrm{m}}=C_{0} \times\left(\mathrm{e}^{(k-g) \times \Delta t}-\right.$ 1)/ $[\Delta t \times(z-g)]$, where $C_{0}$ is the initial concentration of $O$. marina, $z$ denotes the $O$. marina population growth rate in the control without ciliates, and $\Delta t$ is the duration of the experiment.

The specific production $(\mathrm{Sp})$ of Condylostoma spatiosum was calculated as $S p=\mu \times v$, where $v$ is the cell volume of $C$. spatiosum. Gross growth efficiency (GGE) was calculated from the idealized curves of $S p$ and $I$ (see 'Response models') according to GGE $=S p \times$ $\mathrm{CC} /(I \times \mathrm{OC} \times v o)$, where $\mathrm{CC}$ is the carbon density of $C$. spatiosum, $\mathrm{OC}$ and vo are the carbon density and cell volume of Oxyrrhis marina, respectively.

Response models. As the prey concentrations changed greatly during the course of each experiment, we related the ingestion rates to mean prey concentrations for the analyses of functional responses. Growth rate, cell volume, and specific production were related to initial prey concentrations for the analyses of numerical responses (see Fig. 1).

To characterize the interactive effect of temperature and prey concentration on specific growth rate, ingestion rate, cell volume, and specific production, we fitted established response models (e.g. Montagnes \& Lessard 1999, Kimmance et al. 2006) to data from our experiments conducted at the 5 temperatures. Curves were generated by an iterative fitting method, using the Marquardt-Levenberg least-squares algorithm. Growth responses, with non-zero intercepts, were established by fitting Eq. (1) to growth rate data. Functional responses were established by fitting Eq. (2) to ingestion rate data. The response of cell volume to prey concentration was established by fitting Eq. (3) to volume data. The response of specific production to prey 
concentration was established by fitting Eq. (4) to specific production data.

$$
\begin{gathered}
\mu=\left[\mu_{\max } \times\left(C_{\mathrm{o}}-p^{\prime}\right)\right] /\left[k_{1}+\left(C_{\mathrm{o}}-p^{\prime}\right)\right] \\
I=I_{\max } \times C_{\mathrm{m}} /\left(k_{2}+C_{\mathrm{m}}\right) \\
V=v_{0}+v_{\text {max }}^{\prime} \times C_{\mathrm{o}} /\left(k_{3}+C_{\mathrm{o}}\right) \\
S p=S p_{\max } \times\left(C_{\mathrm{o}}-p^{\prime}\right) /\left[k_{4}+\left(C_{\mathrm{o}}-p^{\prime}\right)\right]
\end{gathered}
$$

where $\mu_{\max }$ is the maximum specific growth rate; $p^{\prime}$ is the threshold prey concentration (prey $\mathrm{ml}^{-1}$, the concentration where $\mu=0) ; I_{\max }$ is the maximum ingestion rate; $V_{\text {max }}^{\prime}$ is the maximum cell volume influenced by prey concentration; $V_{0}$ is the predicted cell volume at zero prey; $S p_{\max }$ is the maximum specific production; $k_{1}, k_{2}, k_{3}$, and $k_{4}$ are constants.

\section{RESULTS}

At all temperatures, the growth rate, cell volume, specific production, and ingestion rate of Condylostoma spatiosum followed a rectangular hyperbolic response to food concentration (Fig. 1). Three main changes could be recognized in the pattern of growth response with temperature. $\mu_{\max }$ increased linearly (slope $=0.05, \mathrm{p}<0.01$ ) within the range of 12 to $21^{\circ} \mathrm{C}$ and then ran into a relatively stable state within the range 21 to $24^{\circ} \mathrm{C}$ (Fig. 2a). $p^{\prime}$ fluctuated upwards with temperature (Fig. 2b). The initial slope of the numerical response curve $\left(\mu_{\max } / k\right)$ generally increased within the range 12 to $21^{\circ} \mathrm{C}$ and then decreased at $24^{\circ} \mathrm{C}$ (Fig. 2c). The response of $\mu$ of C. spatiosum to the combined effect of temperature $(\theta)$ and $p$ was best described by Eq. (5) $\left(\mathrm{p}<0.01\right.$, adjusted $\mathrm{R}^{2}=0.74$; Fig. 3a):

$\mu=\left\{1.047 \times\left(C_{\mathrm{o}}-1659\right) /\left[4689+\left(C_{\mathrm{o}}-1659\right)\right]\right\} \times 0.026 \times \theta(5)$

The cell volume of Condylostoma spatiosum also increased with food concentration at all temperatures (Fig. 1b). The estimated maximum cell volume slightly decreased with temperature (Fig. 2d). Linear regression $(p=0.036)$ indicated a thermal sensitivity of 0.033 \pm 0.009 (mean $\pm \mathrm{SE}){ }^{\circ} \mathrm{C}^{-1}$ of the maximum cell volume at the reference temperature of $15^{\circ} \mathrm{C}$. The cell volume response of $C$. spatiosum to the combined effect of temperature and food concentration was best described by Eq. (6) ( $\mathrm{p}<0.01$, adjusted $\mathrm{R}^{2}=0.78$; Fig. $\left.3 \mathrm{~b}\right)$ :

$$
V=\left\{\left[8.942 \times C_{\mathrm{o}} /\left(3004+C_{\mathrm{o}}\right)\right]+7.105\right\} \times \theta^{-0.754}
$$

The specific production of Condylostoma spatiosum increased with increasing food concentration (Fig. 1c). The estimated $S p_{\text {max }}$ gradually increased with temperature, with a sharp increase at $21^{\circ} \mathrm{C}$, before falling back to previous levels at $24^{\circ} \mathrm{C}$ (Fig. 2e).

The ingestion rate of Condylostoma spatiosum increased with increasing temperature and food con- centration (Fig. 1d). The estimated maximum ingestion rate increased from about 23 to 50 prey cells predator $^{-1}$ $\mathrm{h}^{-1}$ (corresponding to 0.023 to $0.086 \mathrm{~h}^{-1}$ when normalized against predator volume according to Hansen et al. 1997) within the range 12 to $24^{\circ} \mathrm{C}$ (Fig. 2f). The ingestion rate response of $C$. spatiosum to the combined effect of temperature and prey concentration was best described by Eq. (7) $\left(\mathrm{p}<0.01\right.$, adjusted $\mathrm{R}^{2}=$ 0.54; Fig. 3c):

$$
I=\left[23.467 \times C_{\mathrm{m}} /\left(3606+C_{\mathrm{m}}\right)\right] \times(\theta-11.448)^{0.203}
$$

GGE of Condylostoma spatiosum increased rapidly with prey concentration at all temperatures when prey concentration was below a critical level of about $4 \times 10^{3}$ cells $\mathrm{ml}^{-1}$. Above this level, GGE showed different trends with increasing prey concentration at different temperatures: it decreased very slightly at $12^{\circ} \mathrm{C}$, was stable at 15,18 , and $24^{\circ} \mathrm{C}$, and steadily increased at $21^{\circ} \mathrm{C}$. At sub-saturation prey concentrations, GGE increased more rapidly with prey concentration at lower temperatures. At high prey concentrations, GGE dropped from about 45 to $25 \%$ within the temperature range 12 to $18^{\circ} \mathrm{C}$ and showed a further slight decrease at $24^{\circ} \mathrm{C}$. GGE was generally lowest at $21^{\circ} \mathrm{C}$, showing a strikingly different pattern from that at the other temperatures (Fig. 4).

\section{DISCUSSION}

The growth rate, cell volume, specific production, and ingestion rate of Condylostoma spatiosum typically followed a rectangular hyperbolic response to prey concentration at all temperatures. It is possible that some protists may elicit a sigmoidal response, but in most studies the data are rarely sufficiently precise to assess this (Kimmance et al. 2006). We chose the hyperbolic model because it is theoretically wellfounded and the most frequently used to describe the responses of protists to prey concentrations (Fenchel 1986, Montagnes 1996). These responses have often been incorporated into microbial food-web models and their parameters are useful for assessing the autecology of species (Davidson 1996, Weisse et al. 2002).

\section{Maximum growth rate}

The estimated $\mu_{\max }$ of Condylostoma spatiosum was much lower than that of most small ciliates, but fell within the range reported for similar-sized rotifers at comparable temperatures (Hansen et al. 1997). This is reasonable since metabolic rate tends to decrease with body size. Nonetheless, some large ciliates have higher growth rates than smaller ones (Gismervik 

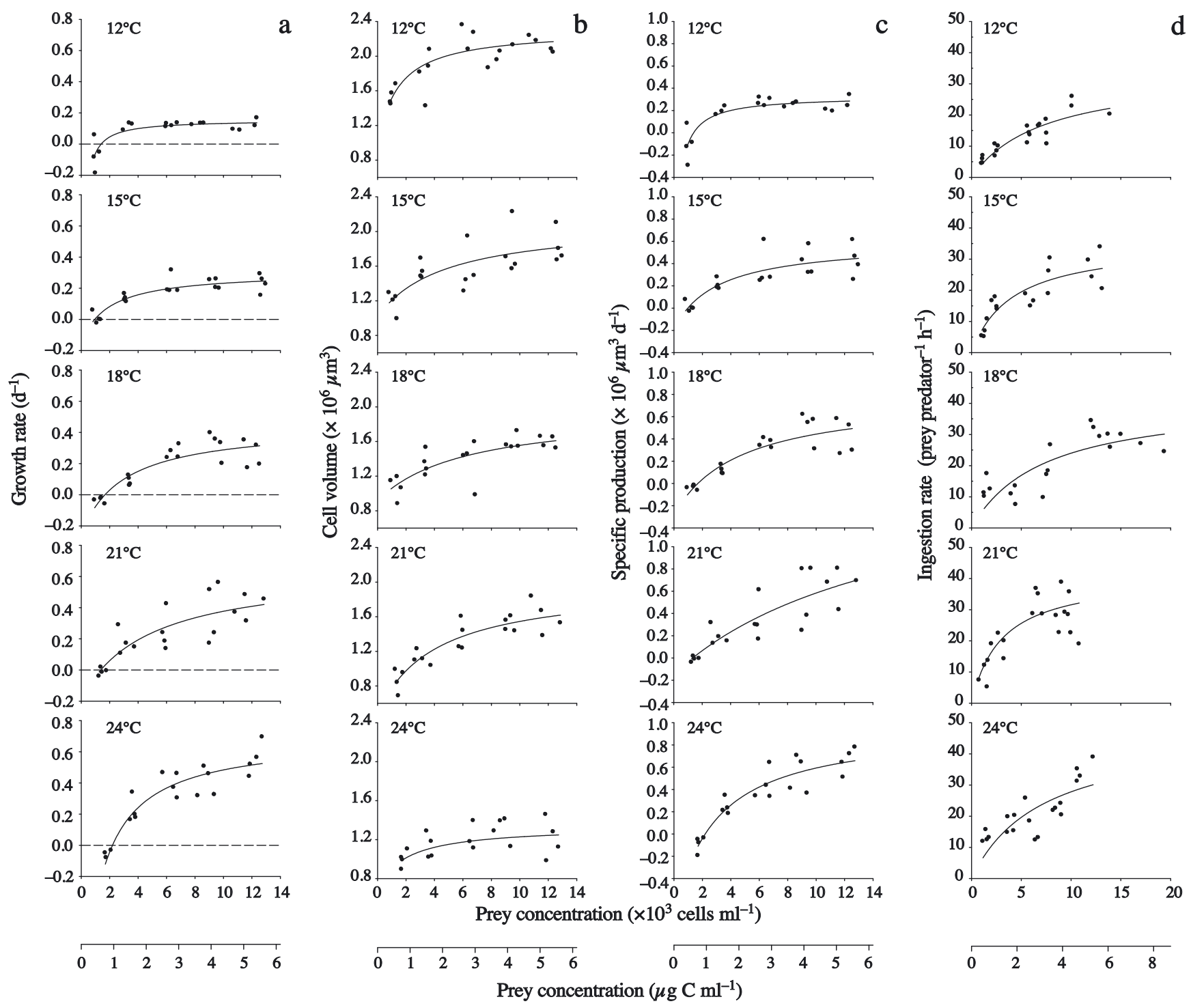

Fig. 1. Condylostoma spatiosum feeding on Oxyrrhis marina. Responses of (a) specific growth rate, (b) cell volume, (c) specific production, and (d) ingestion rate of C. spatiosum to O. marina concentration at temperatures ranging from 12 to $24^{\circ} \mathrm{C}$. Solid curves are the best fit to data. Dashed lines indicate zero growth

2005). Moreover, even identically incubated conspecific ciliates can exhibit conspicuous differences in $\mu_{\max }$ if they were isolated from different habitats (Weisse \& Montagnes 1998, Müller \& Schlegel 1999). Such differences are likely to be attributed to their different regional adaptions. Our data indicate that within the temperature range 12 to $21^{\circ} \mathrm{C}$, the $\mu_{\max }$ typically followed a linear response to temperature, with a slope (i.e. thermal sensitivity) of about $0.05 \mathrm{~d}^{-1}{ }^{\circ} \mathrm{C}^{-1}$. This finding is consistent with the results of Montagnes et al. (2003), who analyzed literature data and suggested a typical linear relationship between $\mu_{\max }$ and temperature for protists, with an average slope of $0.07 \mathrm{~d}^{-1}{ }^{\circ} \mathrm{C}^{-1}$. Since the growth rate as well as the productivity of $C$. spatiosum is less sensitive to tempera- ture than that of its prey (e.g. $0.08 \mathrm{~d}^{-1}{ }^{\circ} \mathrm{C}^{-1}$ for $O x y r$ rhis marina; Kimmance et al. 2006), elevated temperatures would increase the production of the predator at a lower rate than that of its prey and thus reduce competition between predators.

\section{Threshold prey concentration}

We obtained a rather high value for $p^{\prime}$ of $0.237 \mu \mathrm{g} \mathrm{C}$ $\mathrm{ml}^{-1}$ at $15^{\circ} \mathrm{C}$ for the large benthic ciliate Condylostoma spatiosum. Although a $p^{\prime}$ (adjusted to $15^{\circ} \mathrm{C}$ ) as high as $0.325 \mu \mathrm{g} \mathrm{C} \mathrm{ml}{ }^{-1}$ has been recorded, most planktonic ciliates exhibit a $p^{\prime}$ (adjusted to $15^{\circ} \mathrm{C}$ ) ranging from 0.006 to $0.075 \mu \mathrm{g} \mathrm{C} \mathrm{ml}{ }^{-1}$ (Jakobsen \& Hansen 1997 , 


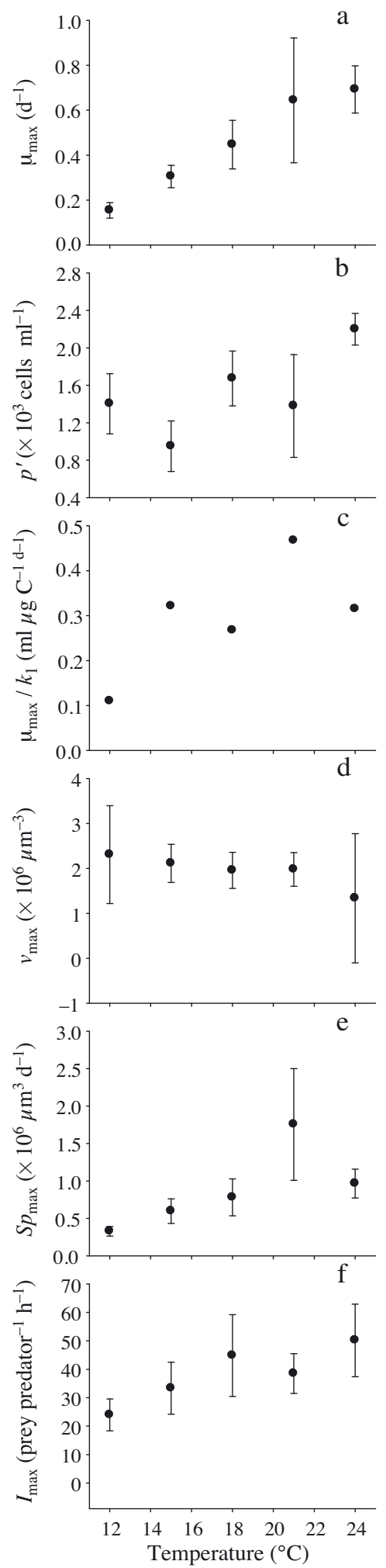

Fig. 2. Condylostoma spatiosum feeding on Oxyrrhis marina. Response of (a) maximum growth rate $\left(\mu_{\max }\right)$, (b) threshold prey concentration $\left(p^{\prime}\right)$, (c) initial slope of numerical response $\left(\mu_{\max } / k_{1}\right)$, (d) maximum cell volume $\left(v_{\max }\right),($ e) maximum specific production $\left(S p_{\max }\right)$, and (f) maximum ingestion rate $\left(I_{\max }\right)$ to temperature. Error bars denote $\pm 1 \mathrm{SE}$
Weisse 2006, and references therein). Usually, high values of $p^{\prime}$ are attributed to suboptimal prey property (prey size, toxicity, nutrient ratio, etc.) or methodological limitations (Müller 1991, Weisse \& Müller 1998). This may partly explain the high $p^{\prime}$ for C. spatiosum
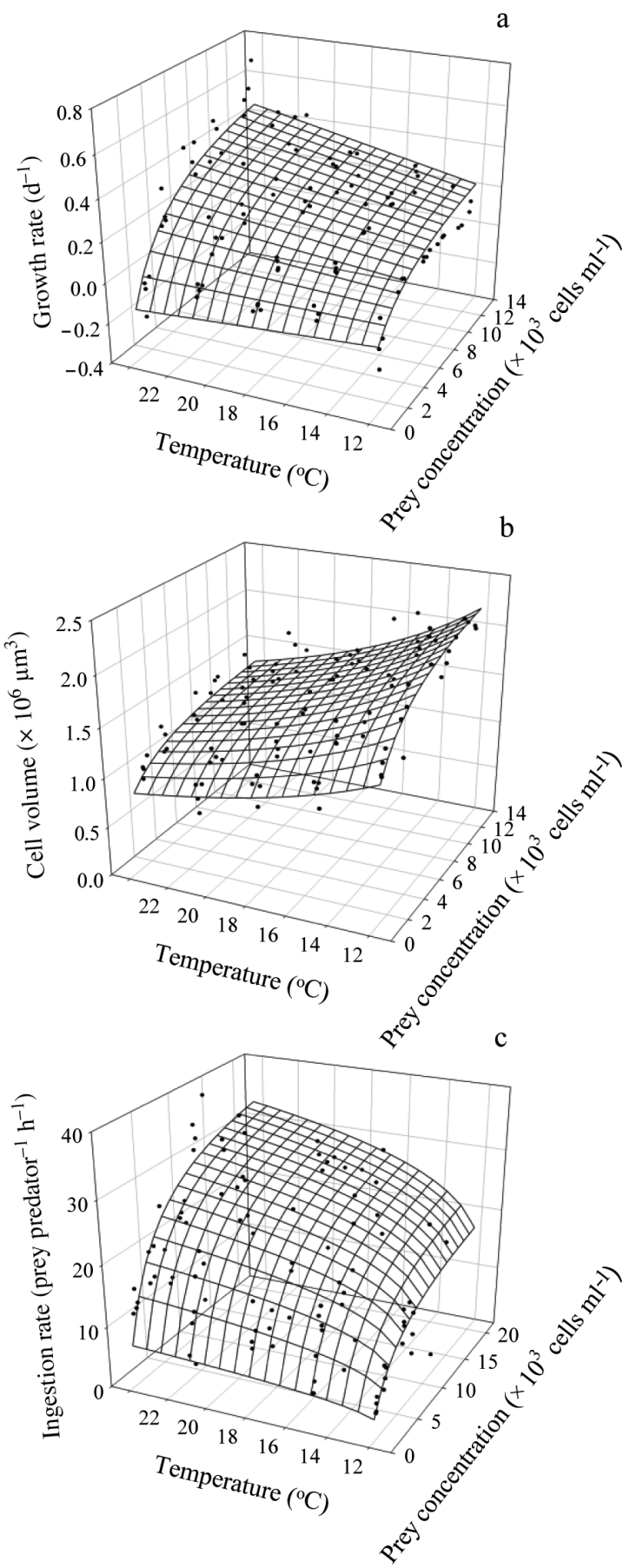

Fig. 3. Condylostoma spatiosum feeding on Oxyrrhis marina. Response of (a) specific growth rate, (b) cell volume, and (c) ingestion rate of $C$. spatiosum to the combined effects of temperature and $O$. marina concentration. Data points obtained from all experiments. Fits to data in (a), (b), and (c) follow Eqs. (5), (6), and (7), respectively 


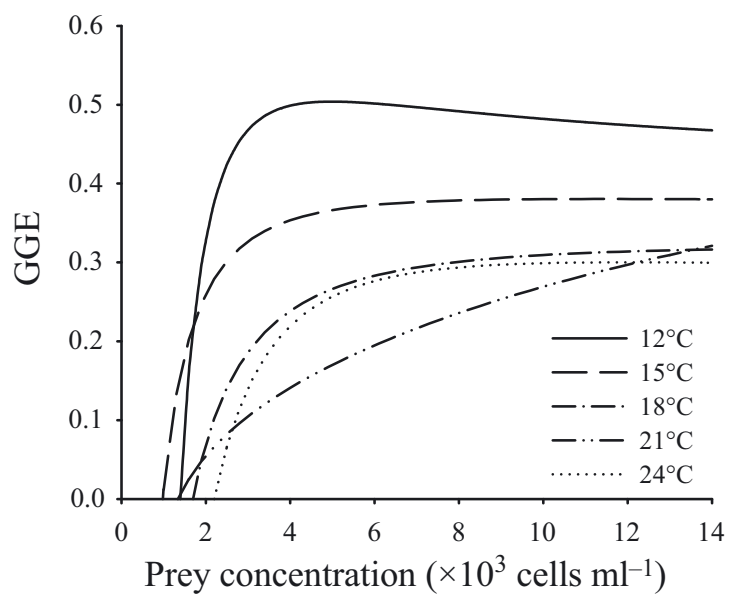

Fig. 4. Condylostoma spatiosum feeding on Oxyrrhis marina. Response of gross growth efficiency (GGE) of C. spatiosum to $O$. marina concentration at temperatures ranging from 12 to $24^{\circ} \mathrm{C}$. Curves were calculated from curves of growth responses and ingestion responses

recorded in the present study, since only one type of food was offered to this large, omnivorous ciliate. The true threshold prey concentration would be lower for C. spatiosum in the field, where an array of various food items is available. On the other hand, considering the different food availability between benthic and planktonic habitats, we have an alternative explanation for the high $p^{\prime}$ for the benthic ciliate. Generally, a lower $p^{\prime}$ confers a selective advantage to species more capable of exploring food at low prey levels. This is essential for ciliates adapted to pelagic water, where prey concentrations are generally low, and thus planktonic ciliates generally present low values of $p^{\prime}$. By contrast, the concentrations of food items are one to several orders higher in benthic environments than planktonic ones (Epstein 1997, Hamels et al. 2004), making the capability of exploring food at low prey levels superfluous for benthic ciliates. This may explain the high threshold prey concentration for $C$. spatiosum and why this ciliate prefers benthic environments, where food items are abundant. However, whether benthic ciliates generally exhibit a $p^{\prime}$ higher than planktonic ciliates needs further investigation.

We are also aware of the fluctuations in $p^{\prime}$ and the initial slope $\left(\alpha=\mu_{\max } / k_{1}\right)$ with increasing temperature for C. spatiosum. For example, $p^{\prime}$ at $12^{\circ} \mathrm{C}$ was higher than that at $15^{\circ} \mathrm{C}(\mathrm{p}=0.14)$, while $\alpha$ was the opposite. Weisse et al. (2002) also observed a high $p^{\prime}$ and low $\alpha$ at low temperatures for the small freshwater ciliate Urotricha farcta and attributed it to temperature stress. However, in the present study, temperature stress could not explain why $p^{\prime}$ was lower $(p=0.08)$ and $\alpha$ was higher at $21^{\circ} \mathrm{C}$. Likewise, Kimmance et al. (2006) observed a lower $p^{\prime}$ for the flagellate Oxyrrhis marina at $15^{\circ} \mathrm{C}$, whereas $p^{\prime}$ increased linearly from 8 to $25^{\circ} \mathrm{C}$. Possibly the relationship between $p^{\prime}$ and temperature is species-specific. On the other hand, experimental error or methodological limitations may also result in deviations (Montagnes \& Berges 2004). Nevertheless, higher $p^{\prime}$ values at high temperatures would mean that a predator dies from starvation rather than being consumed by other predators, and this is critical for modeling food webs (Montagnes 1996).

\section{Maximum cell volume}

Similar to previous studies (Weisse et al. 2002, Kimmance et al. 2006), we observed a linear reduction in $V_{\max }$ with increasing temperature for Condylostoma spatiosum. The slope of the linear regression $\left(-0.03^{\circ} \mathrm{C}^{-1}\right)$ is also close to the average thermal sensitivity of $-0.04{ }^{\circ} \mathrm{C}^{-1}$ suggested by Atkinson et al. (2003). It is still not clear why cell size decreases with temperature. One possible reason is that the reduction in size, and hence increase in the surface area relative to the metabolizing cell mass, is a necessary compensation for the reduced supply to consumption ratio of the limiting resource (e.g. oxygen, carbon dioxide) at high temperatures (Atkinson et al. 2003). But this does not explain similar trends found in other organisms (e.g. fish, amphibians, insects) (Atkinson 1994). An alternative explanation involves separating the effects of temperature on the processes that control cell size and development, i.e. differentiation or change in life stage. Size reduction at high temperature could result from a greater thermal sensitivity of the developmental rate than that of the cell growth rate (Kingsolver \& Huey 2008). Nevertheless, the decrease in cell size with temperature results in a reduction of specific production for C. spatiosum at high temperature $\left(24^{\circ} \mathrm{C}\right)$ while growth rate is still increasing. The effect of temperature on production would be overestimated if the temperature effect on cell size was ignored (Brush et al. 2002, Atkinson et al. 2003).

\section{Maximum grazing rate}

Although the volume-normalized $I_{\max }$ of Condylostoma spatiosum (0.023 to $\left.0.086 \mathrm{~h}^{-1}\right)$ is very low compared to many other ciliates $\left(0.1\right.$ to $\left.0.48 \mathrm{~h}^{-1}\right)$, it overlaps with the range of $I_{\max }\left(0.054\right.$ to $\left.0.17 \mathrm{~h}^{-1}\right)$ reported for similar-sized rotifers (Hansen et al. 1997). The positive linear relationship between $I_{\max }$ and temperature is consistent with that reported by Kimmance et al. (2006). However, the typical sigmoid response of $I_{\max }$ to temperature has also been documented, possibly due to the broad range of temperatures $\left(6\right.$ to $41^{\circ} \mathrm{C}$ ) evalu- 
ated (Montagnes et al. 2001). Nevertheless, an elevated $I_{\max }$ indicates an enhanced feeding activity resulting in higher prey productivity by reducing competition within prey groups, particularly among those very abundant organisms (e.g. diatoms and flagellates) in benthic environments. High values of $I_{\max }$ at high temperatures would also result in high carbon flux in benthic microbial food webs.

\section{Gross growth efficiency}

GGE is useful for assessing the reliability of growth and grazing data (Gismervik 2005), but estimation of GGE is often greatly influenced by environmental factors and methodological protocols. The GGE data obtained from the growth and grazing response curves of Condylostoma spatiosum fall within the interquartile range of 10 to $45 \%$ suggested for ciliates (Straile 1997). At high prey levels, the GGE of C. spatiosum showed different trends with increasing prey concentration at different temperatures. This is consistent with the results of Straile (1997), who analyzed literature data and concluded that the effect of prey concentration on GGE could be either negative or positive depending on the data sets included in the analysis. The mechanisms involved in the response of GGE to prey concentration are complex. A useful framework for understanding this involves dividing GGE (growth/ingestion) into assimilation efficiency $(\mathrm{AE}=$ (growth + respiration $) /$ in gestion) and net growth efficiency (NGE = growth/ (growth + respiration)). Both AE and NGE are influenced by ambient prey concentration. On the one hand, high prey concentration could result in superfluous feeding or insufficient digestion and thus a reduction in AE. On the other hand, NGE might increase at high prey concentrations as energy lost through prey capture decreases with increased prey availability. The synergistic effect of AE and NGE may result in a complex relationship between GGE and prey concentration, as shown both in the present study and previously (Vidal 1980, Straile 1997, and references therein). Fenton et al. (2010), however, demonstrated that, depending on the relationship between the half-saturation constant of the grazing response $\left(k_{2}\right)$ and growth response $\left(k_{1}-p^{\prime}\right), \mathrm{AE}$ could either increase if $k_{2}<\left(k_{1}-p^{\prime}\right)$ or decrease if $k_{2}>\left(k_{1}-p^{\prime}\right)$ with increasing prey concentration. However, NGE derived from the expression for GGE and AE follows a hyperbolic increase relative to prey concentration regardless of the relationship between $k_{2}$ and $k_{1}-p^{\prime}$. That is to say GGE would definitely increase with prey concentration when $k_{2}<\left(k_{1}-\right.$ $\left.p^{\prime}\right)$. Our data suggest that with increasing prey concentration, the GGE pattern at $21^{\circ} \mathrm{C}$ was clearly different from that at the other temperatures. Interestingly, the different patterns coincide with the different relationships between the half-saturation constants of both the grazing and the growth responses of $C$. spatiosum: this relationship was $k_{2}<\left(k_{1}-p^{\prime}\right)$ at $21^{\circ} \mathrm{C}$, while at the other temperatures it was $k_{2}>\left(k_{1}-p^{\prime}\right)$ (data not shown). Therefore the GGE at $21^{\circ} \mathrm{C}$ continuously increased with increasing prey concentration. However, we could not explain why the relationship at $21^{\circ} \mathrm{C}$ was different from those at other temperatures. The different patterns between GGE and prey concentration at different temperatures possibly reflect an interactive effect of prey concentration and temperature.

The GGE at saturated prey concentration generally decreased from about 45 to $25 \%$ with increasing temperature, suggesting a suppression effect of temperature on the GGE of Condylostoma spatiosum. This is consistent with the findings of Straile (1997), who showed that the GGE of ciliates is negatively correlated with temperature. The decline in GGE at high temperatures could be partially explained by the constant carbon density of Oxyrrhis marina used for the calculation of GGE, whereas in fact the carbon density of $O$. marina might decrease with temperature (Montagnes \& Franklin 2001). A more general explanation likely involves the von Bertalanffy-Perrin model, which states that catabolic processes are more sensitive to temperature than anabolic processes (Perrin 1995). In other words, respiration increased more rapidly than cell growth at high temperature, causing a reduction in NGE. Thus, GGE would decrease with temperature unless AE increased appreciably (Malloy \& Targett 1991). In contrast to the negative correlation for ciliates, there is a positive relationship between GGE and temperature for nano- and microflagellates and no significant relationship for rotifers (Straile 1997). Angilletta \& Dunham (2003) also observed positive relationships for many other ectotherms and argued reasons for the failure of the von BertalanffyPerrin model; for example, the assumed allometries of anabolism and catabolism in the model might be unrealistic for some species. The mechanism of the response of GGE to temperature remains enigmatic.

Acknowledgements. This work was supported by the Knowledge Innovation Program of the Chinese Academy of Sciences (no. KZCX2-YW-417) and the Natural Science Foundation of China (no. 40706047). We thank 2 anonymous reviewers for constructive criticism on an early draft of the manuscript.

\section{LITERATURE CITED}

Angilletta M, Dunham AE (2003) The temperature-size rule in ectotherms: simple evolutionary explanations may not be general. Am Nat 162:332-342

Atkinson D (1994) Temperature and organism size: a biological law for ectotherms? Adv Ecol Res 25:1-58 
Atkinson D, Ciotti BJ, Montagnes DJS (2003) Protists decrease in size linearly with temperature: $c a .2 .5 \%{ }^{\circ} \mathrm{C}^{-1}$. Proc R Soc Lond B 270:2605-2611

Begon M, Harper JL, Townsend CR (1986) Ecology: individuals, populations and communities. Blackwell, Oxford

Brush MJ, Brawley JW, Nixon SW, Kremer JN (2002) Modeling phytoplankton production: problems with the Eppley curve and an empirical alternative. Mar Ecol Prog Ser 238: 31-45

Davidson K (1996) Modelling microbial food webs. Mar Ecol Prog Ser 145:279-296

Epstein SS (1997) Microbial food webs in marine sediments. II. Seasonal changes in trophic interactions in a sandy tidal flat community. Microb Ecol 34:199-209

Fenchel T (1968) The ecology of marine microbenthos. II. The food of marine benthic ciliates. Ophelia 5:73-121

Fenchel T (1969) The ecology of marine microbenthos. IV. Structure and function of the benthic ecosystem, its chemical and physical factors, and the microfauna communities, with special reference to the ciliated protozoa. Ophelia 6:1-182

Fenchel T (1986) Protozoan filter feeding. Prog Protistol 1: 65-113

Fenton A, Spencer M, Montagnes DJS (2010) Parameterising variable assimilation efficiency in predator-prey models. Oikos 119:1000-1010

Frost BW (1972) Effects of size and concentration of food particles on feeding behavior of marine planktonic copepod Calanus pacificus. Limnol Oceanogr 17:805-815

Gismervik I (2005) Numerical and functional responses of choreo- and oligotrich planktonic ciliates. Aquat Microb Ecol 40:163-173

Hamels I, Sabbe K, Muylaert K, Vyverman W (2004) Quantitative importance, composition, and seasonal dynamics of protozoan communities in polyhaline versus freshwater intertidal sediments. Microb Ecol 47:18-29

> Hansen PJ, Bjørnsen PK, Hansen BW (1997) Zooplankton grazing and growth: scaling within the $2-2,000-\mu \mathrm{m}$ body size range. Limnol Oceanogr 42:687-704

> Jakobsen HH, Hansen PJ (1997) Prey size selection, grazing and growth response of the small heterotrophic dinoflagellate Gymnodinium sp. and the ciliate Balanion comatum - a comparative study. Mar Ecol Prog Ser 158:75-86

Jeong HJ, Kim JS, Yeong DY, Kim ST, and others (2003) Feeding by the heterotrophic dinoflagellate Oxyrrhis marina on the red-tide raphidophyte Heterosigma akashiwo: a potential biological method to control red tides using mass-cultured grazers. J Eukaryot Microbiol 50: 274-282

Kimmance SA, Atkinson D, Montagnes DJS (2006) Do temperature-food interactions matter? Responses of production and its components in the model heterotrophic flagellate Oxyrrhis marina. Aquat Microb Ecol 42:63-73

Kingsolver JG, Huey RB (2008) Size, temperature, and fitness: three rules. Evol Ecol Res 10:251-268

> Lei Y, Stumm K, Volkenborn N, Wickham S, Berninger UG (2010) Impact of Arenicola marina (Polychaeta) on the microbial assemblages and meiobenthos in a marine intertidal flat. Mar Biol 157:1271-1282

Lowe CD, Day A, Kemp SJ, Montagnes DJS (2005) There are high levels of functional and genetic diversity in Oxyrrhis marina. J Eukaryot Microbiol 52:250-257

Madoni P (2006) Benthic ciliates in Adriatic Sea lagoons. Eur J Protistol 42:165-173

Editorial responsibility: Karel Šimek,

České Budějovice, Czech Republic
Malloy KD, Targett TE (1991) Feeding, growth and survival of juvenile summer flounder Paralichthys dentatus: experimental analysis of the effects of temperature and salinity. Mar Ecol Prog Ser 72:213-223

> Menden-Deuer S, Lessard EJ (2000) Carbon to volume relationships for dinoflagellates, diatoms, and other protist plankton. Limnol Oceanogr 45:569-579

Montagnes DJS (1996) Growth responses of planktonic ciliates in the genera Strobilidium and Strombidium. Mar Ecol Prog Ser 130:241-254

Montagnes DJS, Berges JA (2004) Determining parameters of the numerical response. Microb Ecol 48:139-144

> Montagnes DJS, Franklin DJ (2001) Effect of temperature on diatom volume, growth rate, and carbon and nitrogen content: reconsidering some paradigms. Limnol Oceanogr 46:2008-2018

Montagnes DJS, Lessard EJ (1999) Population dynamics of the marine planktonic ciliate Strombidinopsis multiauris: its potential to control phytoplankton blooms. Aquat Microb Ecol 20:167-181

> Montagnes DJS, Kimmance SA, Tsounis G, Gumbs JC (2001) Combined effect of temperature and food concentration on the grazing rate of the rotifer Brachionus plicatilis. Mar Biol 139:975-979

> Montagnes DJS, Kimmance SA, Atkinson D (2003) Using $Q_{10}$ : Can growth rates increase linearly with temperature? Aquat Microb Ecol 32:307-313

Müller H (1991) Pseudobalanion planctonicum (Ciliophora, Prostomatida): ecological significance of an algivorous nanociliate in a deep meso-eutrophic lake. J Plankton Res 13:247-262

Müller H, Schlegel A (1999) Responses of three freshwater planktonic ciliates with different feeding modes to cryptophyte and diatom prey. Aquat Microb Ecol 17:49-60

Perrin N (1995) About Berrigan and Charnov's life history puzzle. Oikos 73:137-139

Simpson EP, Gonzalez MR, Hart CM, Hurlbert SH (1998) Salinity and fish effects on Salton Sea microecosystems: benthos. Hydrobiologia 381:153-177

Straile D (1997) Gross growth efficiencies of protozoan and metazoan zooplankton and their dependence on food concentration, predator-prey weight ratio, and taxonomic group. Limnol Oceanogr 42:1375-1385

Vidal J (1980) Physioecology of zooplankton. IV. Effects of phytoplankton concentration, temperature, and body size on the net production efficiency of Calanus pacificus. Mar Biol 56:203-211

- Weisse T (2006) Freshwater ciliates as ecophysiological model organisms - lessons from Daphnia, major achievements, and future perspectives. Arch Hydrobiol 167:371-402

Weisse T, Montagnes DJS (1998) Effect of temperature on inter- and intraspecific isolates of Urotricha (Prostomatida, Ciliophora). Aquat Microb Ecol 15:285-291

Weisse T, Müller H (1998) Planktonic protozoa and the microbial food web in Lake Constance. Arch Hydrobiol Spec Issue Adv Limnol 53:223-254

> Weisse T, Stadler P, Lindström ES, Kimmance SA, Montagnes DJS (2002) Interactive effect of temperature and food concentration on growth rate: a test case using the small freshwater ciliate Urotricha farcta. Limnol Oceanogr 47 : $1447-1455$

Submitted: December 8, 2010; Accepted: May 30, 2011 Proofs received from author(s): July 18, 2011 